\title{
Lawrence Schlemmer - South African Pioneer of Social Indicators and Applied Quality of Life Research
}

\section{Valerie Møller ${ }^{1}$}

Published online: 16 November 2020

(C) The International Society for Quality-of-Life Studies (ISQOLS) and Springer Nature B.V. 2020

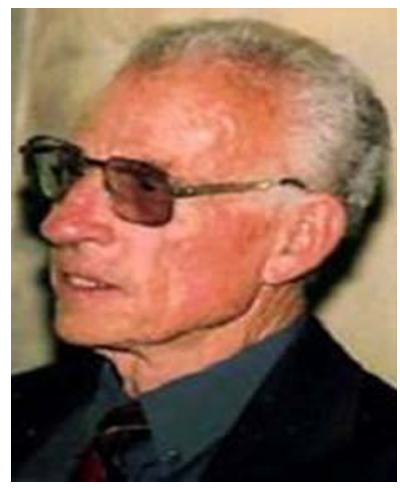

We have Lawrence Schlemmer to thank for launching South Africa's social indicator movement and applied quality-of-life studies on the African continent. With his new empirical approach, he inspired a whole generation of South African social scientists at a time when most were predominantly engaged in ideological discourse.

Lawrence Schlemmer's life work aimed to give voice to South Africans from all walks of life, so that political leaders should know what ordinary people's hopes were for themselves, their families, and their society. Lawrence understood South Africa's complex society as a remarkable laboratory for the social sciences.

Initiating South African Quality-of-Life Studies Quality-of-life scholars typically start by examining what is important for a life of quality in their own research context and culture. I well remember the day, it will have been a Friday in late 1978, when Professor Schlemmer appeared in my office in the Centre for Applied Social Sciences at the University of Natal with two books in hand and proposed we start studying South Africans' perceptions of their own quality of life. Although the country's white president often referred to smiling black South African faces as proof they were happy, our research would soon indicate this was not the case.

Valerie Møller

v.moller@ru.ac.za

1 Institute of Social and Economic Research, Rhodes University, Grahamstown, South Africa 
That weekend, I read the classic works on quality of life by Andrews and Withey (1976) and Campbell and his colleagues (1976), cover to cover. Once I'd filed my report on Monday, Lawrence and I set to work sorting through lists of South African concerns that had been collected in focus group discussions with black South Africans in the sprawling townships surrounding Johannesburg, the economic hub that attracts work seekers from across the country. Lawrence's first practical assignment as a rookie social worker had been to serve single-handedly as township administrator for one of the Johannesburg townships. Based on that first-hand experience, he reckoned that concerns of township dwellers in the area would reflect those of the vast majority of black South Africans.

Initially, Lawrence and I tested the salience of hundreds of the concerns voiced by the focus group discussants in several rounds of research, first with black South Africans, then with the other population groups, before piloting South Africa's first quality-of-life survey through the Human Sciences Research Council's (HSRC) survey capability. The HSRC's trained fieldworker teams conducted personal interviews with respondents in their home languages to ensure questions were understood properly. To comply with apartheid restrictions of movement, each racial group was sampled separately, so country-level scores of satisfaction with life had to be calculated based on weighted results across four apartheid subsamples.

The South African Quality-of-Life Trends Study Following the Andrews and Withey research approach, all our indicators were formulated as satisfaction items. They covered overall life satisfaction and happiness, as well as satisfaction with a wide range of domains and sub-domains. Originally, Lawrence had envisaged that we would regularly field a smaller set of the key global and domain-level satisfaction indicators. Unfortunately, owing to limited finance, later rounds of what became known as the South African Quality-of-Life (SAQoL) Trends study had to make do with just the three core measures: overall life satisfaction, global happiness, and whether life was getting better or worse. Our first reports on the original multi-dimensional SAQoL Trends study in the 1980s were published both locally and in the international Social Indicators Research journal (Møller 1989; Møller and Schlemmer 1983, 1989). A later wave of the SAQol Trends study captured the euphoria following the first open elections of April 1994, when all South Africans, black and white, indicated they were happy and satisfied with life (Møller 1994).

Looking back, many of the initial indicators Lawrence and I selected as most relevant for South African quality of life in the late 1970 s related to the lack of choice and opportunities in life under apartheid for black, coloured and Indian South Africans. A prominent gerontologist once noted that questions posed in repeat studies tend to become 'quaint' over time. Many of our original domain satisfaction indicators referred to choice in housing, access to education and jobs, freedom of movement, personal dignity, and respect received from the community. Since that time, such issues have been addressed in the country's new constitution, that guarantees human rights for all. South Africa's millennials, the so-called 'born frees', now take these freedoms for granted. Our approach to measuring South African quality of life was also criticised for inviting individuals to assess their personal well-being in a society that still holds many collectivist values. Indeed, some of our older black respondents were less concerned about their own opportunities in life than those of their grandchildren. They suggested we ask them instead how satisfied they were with their children's or grandchildren's education.

Prospects for Peaceful Change What sparked Lawrence's idea of pursuing social indicators and quality-of life research? Possibly it was his earlier collaboration with Theodor Hanf on the ambitious mid-1970s study of 'Prospects for Peaceful Change' in South Africa. Hanf, director of the Arnold Bergstraesser Institute in Germany, specialised in studying conflict and peaceful solutions in troubled and divided nations in many parts of the world. His empirical enquiry into the possibility of democratic conflict regulation in South Africa studied hopes and fears for the future among both white and black citizens. Along with questions on their socio-political views, Hanf's team asked black urban respondents to rate their happiness on a five-point scale, that showed faces described to them as being 'very happy' 'happy', 'not happy but also not unhappy - in the middle', 'unhappy' or 'angry and impatient' (emphasis added, Hanf et al. 1981, p.467). The 'angry and impatient' wording of the negative end-anchor of Hanf's happiness scale instead of the conventional 'very unhappy' will have been chosen specifically for a society as divided as South Africa in the 1970s. This choice of phrasing might be compared with the non-linear Andrews and Withey (1976) 'delighted' - 'terrible' scale that uses a number of different labels to describe points on a well-being continuum.

Following on the first wave of interviews with urban black respondents conducted by Hanf's survey team, Lawrence doubled the overall sample size in two further waves of research with six additional subsamples, to n3282 happiness ratings. This combined research effort indicated clearly that anger had increased among urban black South Africans between 1977 and 1979 (see Table P.3, in Hanf et al. 1981, p. 442). 
Indicators for Africa In the 1980s, with his sights on the future, Lawrence initiated a number of projects that would prepare for South Africa's transition to an open society. Indicator South Africa, produced by a small editorial and production team in his Durban research centre, published a quarterly barometer that documented change in South African society in 'real' time - in the non-digital age before social media and the internet. It is said that Nelson Mandela relied on Indicator SA to keep abreast of developments while in prison. Its unique format consisted of separate monitors that focused on specific domains of life, such as politics, economics, education, health, housing, and safety. The editors of Indicator SA were experienced journalists, who ensured reporting was forthright and concise. Their choice of title for our first report on South African quality of life in the late 1970s was the Rolling Stones' 'Can't Get No Satisfaction' (Møller 1989).

Schlemmer's contribution to the first issue of Indicator SA was an essay on the difficult task of giving a balanced interpretation of what constitutes meaningful change in South Africa. At the time, he wrote, there was virtually no consensus in the public debate on change and reform. This seminal article set out a framework as an attempt to reach a consistent and comprehensive method of assessing change. He argued that prospects for change in South Africa must be established in terms of this structure and must reflect all the complexities of a divided society, whose divisions are not simply those of race or ethnicity. His model of South African society in the early 1980s was to be understood in terms of four principles of division: political power, class, citizenship, and inclusion-exclusion. These dividing principles were superimposed on one another in the complex pattern of South African society (Schlemmer 1983).

Using this framework, Lawrence tracked South Africa's transition from apartheid to democracy in 38 articles that appeared mainly in Indicator SA's political monitor between 1983 and 1994. His contributions monitored political trends and provided critical diagnosis of developments during the turbulent 1980s. He reported views of ordinary black workers, trade union and resistance leaders, as well as those in power. Data trends from opinion surveys commissioned for Indicator SA monitored shifts in attitudes to change among the different political groupings and factions in society that led to the negotiations for a political settlement (Schlemmer 1983-1993, 1994).

Articles reporting the views of black workers and township dwellers in Indicator SA focused on the issues and political unrest that signalled the urgent need for social reform under the titles: 'Black urban unrest - how serious is the problem?' (1983), 'Black wage aspirations - are politics a factor?' (1984), 'Black factory workers' views on the role of trade unions in their lives' (1984), 'Political unrest and African rights: Part One, Reform and rejection' (1984), 'African political rights: Part Two, Reform and acceptability' (1984), 'Township unrest - as seen by township residents' (1985), 'Black workers \& the alternative - attitudes towards socialism' (1985), 'The sanctions surveys - in search of ordinary black opinion' (1986).

Noteworthy is that Lawrence's Indicator SA articles on the stony path to South Africa's political settlement recorded history in the making. Their titles tell the story of the advances and set-backs on the journey from apartheid to the first democratic elections a decade later: 'White voter preferences - predictable trends' (1983), 'South Africa after the referendum' (1983), 'Government supporters: Yesterday and today' (1983), 'Change: South Africa's split personality' (1984), 'The public image of white political leaders and the myth of hallowed leadership' (1984), 'The spectre of right wing resurgence - how threatened is the state?' (1984), 'The government reform agenda' (1985), 'White reactions - political attitudes \& by-elections' (1986), 'Unrest the emerging significance' (1986), 'South Africa in mid-1986 - stress \& stalemate' (1986), 'Apartheid in transition - the collapse of racial zoning' (1986), 'Ruling party politics - circling around the May-poll' (1987), 'After Soweto and Sebokeng - the elections of ' 77 and ' 87 ' (1987), 'Factionalism in resistance movements' (1988), 'Liberal white opposition - the strategic dilemma' (1988), 'October 1988 - dress rehearsal without a script' (1988), 'Dialogue with the resistance - introductory comment' (1989), 'Dialogue after Dakar: Part II, Risks and rewards' (1989), 'De Klerk's Five Options - a mandate for change' (1989), 'Transition in South Africa - frontstage and backstage' (1989), 'Mixed signals - the nationalisation debates' (1990), 'Minority rights and political justice - the dilemmas of settlement' (1990), 'Between polarisation and pacts - what kind of transition does South Africa have?' (1990), 'No easy path to pluralism' (1990), 'Negotiation dilemmas after the sound and fury' (1991), 'Social contracts - a recipe without ingredients' (1991), 'Codesa after the referendum' (1992), 'South Africa in the shadow of the past' (1992), 'Birth of democracy' (1994).

Schlemmer's expertise as political analyst and commentator was always in great demand during the 1980s and 1990s. He spoke with confidence on a wide range of issues, off the cuff, in both English and Afrikaans, and to all manner of audiences. He also managed to adapt his manner of both speech and dress to suit different audiences, wearing a particularly sober suit when invited to brief party politicians and government officials of the apartheid era. As director of the survey company MarkData, formed in 1996, his expert knowledge of South Africa's data trends continued to be sought after in the new South Africa (Schlemmer 2008).

Ahead of the Times Lawrence Schlemmer was an independent thinker who held strong liberal views. He was ahead of the times when he appointed black staff in his research centre. My first task upon joining 
Lawrence's team in 1976 was to produce a joint research report, with a young political activist who had just completed a prison sentence on the notorious Robben Island. Lawrence had given him work collecting data on township life to inform an international donor who was to sponsor a community project.

Lawrence's institute was also among the first university departments given permission to offer courses in applied social science to both black and white students in the 1980s. Our classes were seated at a round seminar table and held after hours to accommodate the mature black students, many of whom were employed as professionals and had far greater life experience than their younger white classmates.

Education and skills training were in short supply for black South Africans under apartheid. Lawrence initiated a Community Service Training Programme (CSTP), which offered theoretical and practical training for prospective community workers to administer development programmes. An extension of his research centre in Durban, the CSTP accepted only applicants with genuine interest in community development rather than ones who sought to add another qualification to their vitae. Trainees were recruited regardless of their political affiliations, and of necessity would gain experience of working together - an essential skill for future citizens of South Africa's multi-party democracy.

Work Life with Schlemmer Doing empirical research with Lawrence Schlemmer was always fun. His approach was practical, imaginative, and at times unconventional. He passed on his fascination and curiosity about society to all who worked alongside him. Lawrence had supported the 1973 dockworkers strikes in Durban. He believed that the opinions of ordinary people should be consulted when shaping social policy. He had a knack for formulating nuanced research questions that found rapport with respondents from all walks of life, and a flair for interpreting complex patterns in survey results.

Work life with Lawrence Schlemmer was also never dull! When I joined his institute in 1976, I was warned our phones might be tapped. The following year, my black colleagues tipped me off that a government informer was posing as a member of our fieldworker team. The only computer printouts of our quality-of-life baseline data were almost destroyed when Lawrence's home and then our university offices were firebombed in 1986. Lawrence was the first on the scene and managed to salvage the charred printouts, that reeked of smoke for many years.

A workaholic and chain-smoker, Lawrence was known to work through the night only to jet off the next morning to address an audience somewhere. Members of his staff knew they would be kept too busy to find time to write their $\mathrm{PhD}$ theses. Lawrence himself only got round to writing his doctoral dissertation late in life, by then he was equipped with incomparable knowledge and a sense of history as South Africa's leading political commentator and analyst. I doubt Lawrence ever took the trouble to list his many publications. He simply stored them in a big cupboard in his office, out of sight.

Affectionately known as Lawrie by family and friends, Lawrence had a quick wit and sense of humour, and also a creative bohemian streak. His creativity was not limited to designing surveys and interpreting data. He had studied art at the University of Pretoria under Walter Battis, known as a 'gentle anarchist'. Lawrence's doodles were always of characterful vintage cars, like the ones he kept in his back garden wherever he lived. He enjoyed tinkering with his favourite Citroëns and Chyrslers and sculpting the driftwood he collected on the beaches where he walked his dogs. Once, when visiting Durban for a meeting that ended later than anticipated, he chose to sleep on the beach rather than booking into an hotel before flying home to Johannesburg the next morning.

Background Lawrence Schlemmer was born in Pretoria, South Africa, on 11 September 1936 into a bilingual Afrikaaner family. He earned his Bachelor and Honours degrees in 1958 and 1960 from the University of Pretoria majoring in Sociology, Criminology, English and Demography, and also studied Psychology through the University of South Africa.

During his lifetime, Lawrence founded, headed or consulted for numerous South African think tanks including the Urban Foundation, the Centre for Policy Studies, and the Centre for Development and Enterprise. He was Director of the Helen Suzman ${ }^{1}$ Foundation and Vice-President of the South African Institute of Race Relations, which received the International Society for Quality-of-Life Studies' Betterment of Humankind award in 2006 for its commitment to reporting inclusive social indicators. He authored or co-authored some 15 books and over 300 publications - including a paper that attracted the 1997 Social Indicators Research best paper award (Giliomee et al. 1994; Giliomee and Schlemmer 1985, 1989; Johnson and Schlemmer 1996; Schlemmer and Møller 1997).

\footnotetext{
${ }^{1}$ Helen Suzman was the only member of the opposition Progressive Party in the South African parliament for a period of 13 years. She consistently and unequivocally opposed all apartheid legislation and was known to use parliamentary privilege to pass information to the media about the worst abuses of apartheid.
} 
Lawrence Schlemmer's academic positions included Professor and Director of the Centre for Applied Social Sciences and Dean of Social Sciences at the then University of Natal, Durban; Professor and Research Director in the Graduate School of Business at the University of the Witwatersrand; Vice-President of the Human Sciences Research Council; and Research Associate at the Arnold Bergstraesser Institute in Germany. He played key roles as member of the Academy of Science of South Africa, the Association for Sociology in Southern Africa, and the South African Political Studies Association. Lawrence Schlemmer never stopped working. After retiring from his academic positions, he continued to act as consultant to many nongovernmental organisations on a wide range of social issues including environmental impact assessments. He was awarded a PhD in political studies from the University of Cape Town in 1999.

Lawrence Schlemmer died in Cape Town on 26 October 2011, aged 75. His wife Monica Bot, then editor of Indicator SA's education monitor, son Julian, and his 'born free' daughter Lucia, survive him.

Legacy Lawrence Schlemmer's legacy as South Africa's senior electoral analyst and pollster continues today. South Africa's first quality-of-life surveys in the late 1970s were conducted in collaboration with the Human Sciences Research Council (HSRC) (Møller et al. 1987). In the new South Africa, HSRC colleague and co-author Benjamin Roberts, whose research career started in Schlemmer's Durban research institute, continues to track SAQoL Trends and the state of the nation through the annual South African Social Attitudes Survey (SASAS) (Roberts et al. 2010). Following in Lawrence Schlemmer's footsteps is a whole new generation of quality-of-life researchers intent on shaping a better life for future generations of South Africans.

\section{References}

Andrews, F. M., \& Withey, S. B. (1976). Social indicators of well-being. New York: Plenum Press.

Campbell, A., Converse, P. E., \& Rodgers, W. L. (1976). The quality of American life. New York: Russell Sage Foundation.

Giliomee, H., \& Schlemmer, L. (Eds.). (1985). Up against the fences: Poverty, passes and privilege in South Africa. Cape Town and Johannesburg: David Philip.

Giliomee, H., \& Schlemmer, L. (Eds.). (1989). Negotiating South Africa's future. Johannesburg: Southern Book Publishers.

Giliomee, H., Schlemmer, L., with Hauptfleisch, S. (1994). The bold experiment: South Africa's new democracy. Johannesburg, Southern Book Publishers.

Hanf, Th., Weiland, H., \& Vierdag, G. in collaboration with Schlemmer, L, Hampel, R., \& Krupp, B. (1981). South Africa: The prospects of peaceful change. London: Rex Collings.

Johnson, R. W., \& Schlemmer, L. (1996). Launching Democracy in South Africa: The first open election, April 1994. New Haven/London: Yale University Press.

Møller, V. (1989). Can't get no satisfaction: Quality of life in the 1980s. Indicator South Africa, 7(1), 43-46. https://journals.co.za/content/indisa/7/1/AJA0259188X_1560?fromSearch=true. Accessed 28 October 2020.

Møller, V. (1994). Post-election Euphoria. Indicator South Africa, 12(1), 27-32. https://journals.co.za/content/ indisa/12/1/AJA0259188X 477?fromSearch=true. Accessed 28 October 2020.

Møller, V., \& Schlemmer, L. (1983). Quality of life in South Africa: Towards an instrument for the assessment of quality of life and basic needs. Social Indicators Research, 12, 225-279.

Møller, V., \& Schlemmer, L. (1989). South African quality of life: A research note. Social Indicators Research, 21(3), 279-291.

Møller, V., Schlemmer, L., \& du Toit, S. H. C. (1987). Quality of life in South Africa: Measurement and analysis. Pretoria: Human Sciences Research Council.

Roberts, B., Wa Kivilu, M., \& Davids, Y. D. (Eds.). (2010). South African social attitudes: The 2nd report: Reflections on the age of hope. Pretoria: HSRC Press.

Schlemmer, L. (1983). Analysing change in South Africa. Indicator South Africa, 1(1), 3-6. https://journals. co.za/content/indisa/1/1/AJA0259188X_579?fromSearch=true. Accessed 16 October 2020.

Schlemmer, L. (1983-1993). Indicator South Africa articles, see https://journals.co.za/search? sortDescending=false \&facetNames=author_facet+pub_serialIdent_facet\&operator $2=A N D \& v a l u e 2=\%$ 27Lawrence+Schlemmer\%27\&value $1=\mathrm{L}+\overline{\mathrm{S}} \mathrm{Chlemmer} \&$ sortField=prism publicationDate $\&$ pageSize $=$ $60 \&$ option $1=$ fulltext\&facetOptions $=2+3 \&$ option $2=$ auhor_facet\&operator $3=$ AND\&option $3=$ pub_ serialIdent_facet\&value3=\%27journal\%2Findisa\%27. Accessed 6 October 2020. 
Schlemmer, L. (1994). Birth of democracy. Indicator South Africa, 11(3), 17-22. https://journals.co.za/ content/indisa/11/3/AJA0259188X_1363?fromSearch=true. Accessed 28 October 2020.

Schlemmer, L. (2008). Deepening democracy in South Africa: Challenges and prospects. Discourse, 36(2), 0 8. https://journals.co.za/content/discourse/36/2/AJA0000004_58?fromSearch=true. Accessed 28 October 2020 .

Schlemmer, L., \& Møller, V. (1997). The shape of South African society and its challenges. Social Indicators Research, 41(1-3), 15-50.

Publisher's Note Springer Nature remains neutral with regard to jurisdictional claims in published maps and institutional affiliations. 